\title{
Analisis Nilai Tambah Produk Rumah Potong Hewan (Studi Kasus RPH Kategori I dan RPH Kategori II)
}

\author{
Analyze Of The Added Value in Slaughtering House (study case Abattoir category I and Abattoir category \\ II) \\ F. Juharii ${ }^{1)}$, H. Nuraini $^{2)}$ \& L. Cyrilla ${ }^{2)}$ \\ 1) Program Studi Ilmu Produksi dan Teknologi Peternakan, Sekolah Pascasarjana, Insitut Pertanian Bogor; \\ 2) Departemen Ilmu Produksi dan Teknologi Peternakan, Fakultas Peternakan, Institut Pertanian Bogor; Jln. \\ Agatis, Kampus IPB Dramaga Bogor 16680, Indonesia
}

\begin{abstract}
Abattoir categories I and II have different handling processes, abattoir category I without chilling facilites to produce hot carcass and abattoir category 2 with chilling facilities to produce chilled carcass . The objective of this study was to analyze the added value generated in abattoir category $I$ and in abattoir category II, as well as to analyze the factors that affect the amount of added value. This study calculated the amount of added value that abattoir Category I and II could create using Hayami Method. The obtained results showed that abattoir category II produced added value of Rp 44358 and Rp 45489 per $1 \mathrm{~kg}$ of carcass and Rp 6552 and Rp 7022 per $1 \mathrm{~kg}$ edible offal, while in abattoir category I the produced added value was much lower that is equal to $R p 25924$ and $R p 25072$ per $1 \mathrm{~kg}$ carcass and Rp 3097 and Rp 4361 per $1 \mathrm{~kg}$ edible offal. The difference of this added value was caused by several factors, one of the most influential factor was the selling price of the product value, in abattoir category II there wasa process of foraging meat (chilling), cooling and packaging of meat divided into Prime Cut, Secondary Cut, Bone, and By Product.
\end{abstract}

Keywords: added value, abattoir

\section{PENDAHULUAN}

Konsumsi daging setiap tahunnya mengalami peningkatan, pada tahun 2010 konsumsi daging sebesar $1,76 \mathrm{~kg}$ kapita $^{-1}$ tahun $^{-1}$ menjadi 2,56 kg kapita ${ }^{-1}$ tahun $^{-1}$ pada tahun 2014 (Data Badan Pusat Statistik 2014). Daging adalah salah satu produk industri peternakan yang dihasilkan dari usaha pemotongan hewan. Seiring semakin banyaknya permintaan masyarakat terhadap daging yang sehat khususnya daging sapi sebagai sumber utama protein hewani terus meningkat, hal ini menyebabkan intensitas pemotongan juga meningkat, oleh karena itu keberadaan Rumah Pemotongan Hewan (RPH) yang dapat menjaga kualitas, baik dari tingkat kebersihannya, kesehatannya, ataupun kehalalan daging untuk dikonsumsi sangat diperlukan di berbagai daerah seluruh Indonesia.

Peningkatan konsumsi daging terjadi seiring dengan kesadaran konsumen terhadap pentingnya kesehatan. Konsumsi daging yang tinggi harus diimbangi dengan produksi daging dalam jumlah yang tinggi, dimana peningkatan produksi dalam jumlah besar harus ditopang dengan adanya industri yang memiliki teknologi tinggi. Hal inilah yang mengharuskan pemerintah mendirikan Rumah Pemotongan Hewan (Saragih 2010).

Kemajuan teknologi dalam pembangunan peternakan, diantaranya industri pemotongan ternak, akan berdampak pada mutu, kehalalan dan keamanan daging yang dihasilkan. Penetapan aturan dan standar operasional maupun teknis yang ditetapkan dalam Peraturan Menteri Pertanian nomor 13 tahun 2010 sebagai dasar penyelenggaraan fungsi RPH sebagai tempat pelaksanaan pemotongan ternak guna menghasilkan daging yang aman, sehat, utuh, dan halal (ASUH).

Rumah pemotongan hewan adalah kompleks bangunan dengan disain dan konstruksi khusus yang memenuhi persyaratan teknis dan higiene tertentu serta digunakan sebagai tempat memotong hewan potong selain unggas bagi konsumsi masyarakat (SNI 01-6159-1999). Pada pasal 62 UU 41/2014 tentang peternakan dan kesehatan hewan dinyatakan, bahwa pemerintah daerah kabupaten/ kota wajib memiliki rumah pemotongan hewan yang memenuhi persyaratan teknis. Usaha pemotongan hewan, berdasarkan kelengkapan fasilitas proses pelayuaan (aging) karkas, dibedakan menjadi 2 (dua) ketegori yaitu kategori I tanpa fasilitas pelayuan karkas, untuk menghasilkan karkas hangat dan kategori II dengan fasilitas pelayuaan karkas, untuk menghasilkan karkas dingin (chilled) dan/atau beku (frozen) (Nomor 13/Permentan/OT.140/1/2010). Pada RPH kategori I atau bisa disebut RPH tradisional dalam proses pasca pemotongan ternak tidak dilakukan pelayuan, daging atau karkas langsung dibawa oleh pedagang dan dijual 
dalam keadaan panas (Hot meat). Keadaan ini dilakukan karena konsumen lebih menyukai daging panas dari pada daging dingin (chill meat atau frozen meat) (Tawaf, 2012).

Salah satu permasalahan dari banyaknya RPH adalah terdapat RPH yang tidak memiliki fasilitas pelayuan karkas (RPH kategori I) dan yang memiliki fasilitas pelayuaan karkas (RPH kategori II). Dari dua kondisi tersebut peneliti tertarik untuk mengkaji jenis RPH yang memiliki nilai tambah paling tinggi. Pentingnya nilai tambah dalam satu RPH baik kategori I maupun kategori II sangat berpengaruh terhadap tingkat keuntungan masing-masing RPH.

\section{MATERI DAN METODE}

\section{Waktu dan Tempat Penelitian}

Penelitian ini dilaksanakan selama empat bulan yaitu bulan September sampai dengan bulan Desember 2016 di 2 RPH Kategori I yaitu: (A) RPH Bubulak kota Bogor dan (B) RPH Jebbrot Cianjur, kemudian 2 RPH kategori II yaitu: (A) RPH PT Sumber Makanan Sehat dan (B) RPH PT Elders.

\section{Prosedur Penelitian}

Sebanyak 5 ekor sapi siap potong dari keempat RPH ditimbang bobot hidup, bobot potong, bobot karkas panas dan bobot karkas dingin, bobot potongan komersil, bobot non karkas layak konsumsi (edible offal) dan dihitung nilai ekonominya. Kemudian dilakukan analisis nilai tambah menggunakan metode Hayami (1987).

Pada RPH kategori I perhitungan nilai tambah dalam proses pemotongan sapi hanya sampai produk Karkas dan komponen non karkas layak konsumsi (edible offal). Sedangkan pada RPH kategori II perhitungan nilai tambah dalam proses pemotongan sapi sampai menjadi potongan komersial (wholesale cut) dan komponen non karkas layak konsumsi (edible offal).

\section{Peubah yang Diamati}

1. Output sapi $=$ Bobot 5 ekor sapi setelah disembelih yang terbagi dari karkas dan edible offal

2. $\quad$ Input Sapi $=$ Bobot hidup 5 ekor sapi
3. Input tenaga kerja $=$ Harian orang kerja dalam satu kali proses produksi

4. Faktor konversi sapi $=$ Persentase karkas

5. Koefisien tenaga kerja = hasil bagi dari input tenaga kerja dengan bobot hidup sapi

6. Upah rata-rata tenaga kerja

7. Harga output $=$ Harga $1 \mathrm{~kg}$ karkas $/$ edible offal

8. Harga input $=$ Harga $1 \mathrm{~kg}$ sapi hidup

9. Sumbangan input lain = biaya pendukung proses produksi

10. Nilai Output $=$ hasil kali dari faktor konversi dengan harga output rata-rata

11. Nilai tambah $=$ hasil pengurangan dari nilai output dengan harga input dan sumbangan input lain

12. Rasio nilai tambah $=$ hasil bagi antara nilai tambah dengan nilai output

13. Keuntungan $\mathrm{RPH}=$ hasil pengurangan dari nilai tambah dengan pendapatan tenaga kerja

14. Marjin $=$ hasil pengurangan nilai output sapi dengan harga input sapi

\section{Analisis Data}

Penelitian ini menghitung besaran nilai tambah yang mampu diciptakan RPH kategori I dan RPH kategori II menggunakan metode Hayami. Peraturan Menteri Pertanian no 13 tahun 2010 Usaha pemotongan hewan, berdasarkan kelengkapan fasilitas proses pelayuaan (aging) karkas, dibedakan menjadi 2 (dua) ketegori yaitu kategori I tanpa fasilitas pelayuan karkas, untuk menghasilkan karkas hangat dan kategori II dengan fasilitas pelayuaan karkas, untuk menghasilkan karkas dingin (chilled) dan/ atau beku (frozen). Pengukuran nilai tambah ini bertujuan untuk mengetahui besaran nilai tambah yang mampu diciptakan sebagai akibat proses pengolahan RPH tersebut. Perhitungan nilai tambah didasarkan pada satu satuan bahan baku utama yaitu $1 \mathrm{~kg}$ (karkas/edible offal) hasil pemotongan di RPH. Sementara itu untuk karkas dilakukan perhitungan nilai jualnya, yaitu jumlah setiap bagian non karkas dikalikan dengan harga masing-masing. Keuntungan total $\mathrm{RPH}$ adalah penjumlahan dari keuntungan karkas dengan

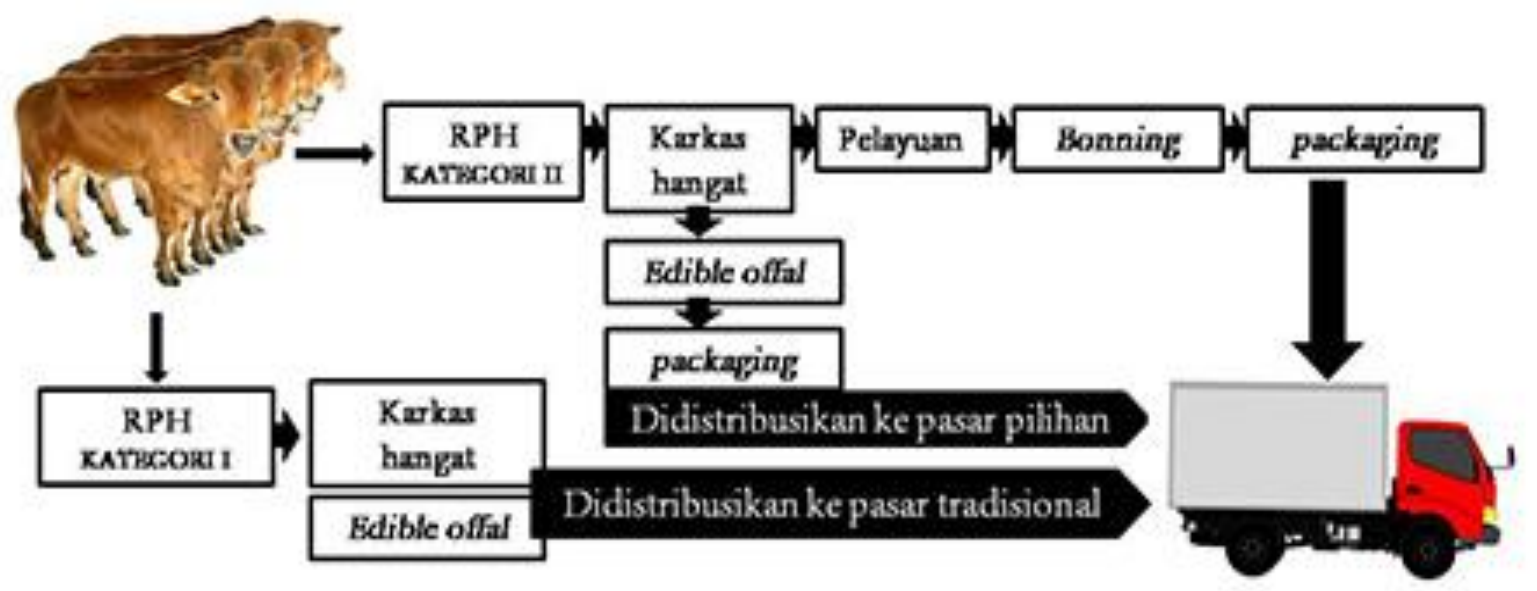

Gambar 1. Diagram alir proses produksi di RPH 
Tabel 1. Kerangka analisis nilai tambah

\begin{tabular}{|c|c|c|}
\hline Variabel & Satuan & Notasi \\
\hline \multicolumn{3}{|l|}{ Output,input dan harga } \\
\hline Output sapi & $\mathrm{kg} /$ proses produksi & A \\
\hline Input bahan baku & $\mathrm{kg} /$ proses produksi & B \\
\hline Input tenaga kerja & $\mathrm{HOK} /$ proses produksi & $\mathrm{C}$ \\
\hline Faktor konversi & $\mathrm{Kg}$ output/Kg bahan baku & $\mathrm{D}=\mathrm{a} / \mathrm{b}$ \\
\hline Koefisien tenaga kerja & $\mathrm{HOK} / \mathrm{Kg}$ bahan baku & $\mathrm{E}=\mathrm{c} / \mathrm{b}$ \\
\hline Harga Output & $\mathrm{Rp} / \mathrm{Kg}$ & $\mathrm{F}$ \\
\hline Upah rata-rata tenaga kerja & $\mathrm{Rp} /$ proses produksi & G \\
\hline \multicolumn{3}{|l|}{ Pendapatan dan Keuntungan } \\
\hline Harga input bahan baku & $\mathrm{Rp} / \mathrm{Kg}$ & $\mathrm{H}$ \\
\hline Sumbangan input lain & $\mathrm{Rp} / \mathrm{Kg}$ & I \\
\hline Nilai Output & $\mathrm{Rp} / \mathrm{Kg}$ & $J=d \times f$ \\
\hline Nilai tambah & $\mathrm{Rp} / \mathrm{Kg}$ & $\mathrm{K}=\mathrm{j}-\mathrm{h}-\mathrm{i}$ \\
\hline Rasio nilai tambah & $\%$ & $\mathrm{~L}=\mathrm{k} / \mathrm{j} \times 100 \%$ \\
\hline Pendapatan tenaga kerja & $\mathrm{Rp} / \mathrm{Kg}$ & $M=e \times g$ \\
\hline Bagian tenaga kerja & $\%$ & $\mathrm{~N}=\mathrm{m} / \mathrm{k} \times 100 \%$ \\
\hline Keuntungan RPH & $\mathrm{Rp} / \mathrm{Kg}$ & $\mathrm{O}=\mathrm{k}-\mathrm{m}$ \\
\hline Bagian Keuntungan & $\%$ & $\mathrm{P}=\mathrm{o} / \mathrm{j} \times 100 \%$ \\
\hline \multicolumn{3}{|l|}{ Balas jasa untuk faktor produksi } \\
\hline Marjin & $\mathrm{Rp} / \mathrm{Kg}$ & $Q=j-h$ \\
\hline a. Pendapatan tenaga kerja & $\%$ & $\mathrm{R}=\mathrm{m} / \mathrm{q} \times 100 \%$ \\
\hline b. Sumbangan input lain & $\%$ & $\mathrm{~S}=\mathrm{i} / \mathrm{q} \times 100 \%$ \\
\hline c. Keuntungan & $\%$ & $\mathrm{~T}=\mathrm{o} / \mathrm{q} \times 100 \%$ \\
\hline
\end{tabular}

Hayami et al. (1987)

keuntungan non karkas. Kerangka analisis nilai tambah menurut Hayami (1987) dapat dilihat dalam Tabel 1.

\section{HASIL DAN PEMBAHASAN}

Pada Gambar 1 diketahui bahwa RPH kategori II memiliki rantai yang lebih panjang dibandingakan RPH kategori I, RPH kategori II memiliki efisiensi yang cukup baik, dari segi peralatan, sumber daya manusia, dan fasilitas pelayuaan karkas untuk menghasilkan karkas dingin (chilled) dan/atau beku (frozen) serta RPH kategori II menghasilkan potongan karkas komersil (wholesale cut) berbeda dengan RPH kategori I pemotongan ternak masih dilakukan dengan cara sederhana, yaitu pemotongan ternak dan prosesing daging dilakukan secara manual. Dalam proses pasca pemotongan ternak, tidak dilakukan pelayuan, karkas langsung dibawa oleh pedagang dan dijual dalam keadaan panas (hot meat).

Menurut Tawaf (2012) dalam Seminar Nasional IV Peternakan Berkelanjutan mengatakan pada RPH tradisional hampir tidak pernah melakukan pelayuan, daging atau karkas langsung dibawa oleh pedagang dan dijual dalam keadaan panas (hot meat). Keadaan ini dilakukan karena konsumen lebih menyukai daging panas dari pada daging dingin (chill meat atau frozen meat), kenyataan tersebut yang menyebabkan turunan bisnis pemotongan sapi yang berlanjut pada kegiatan "prosessing meat" atau "meat handling" berjalan dan dilakukan secara terpencar di masing-masing pasar yang mengakibatkan bisnis ini tidak efesien.

Rumah pemotongan hewan kategori II memiliki pilihan pasar yang lebih luas dibandingkan rumah pemotongan hewan kategori I, RPH kategori II dapat menjangkau pasar modern ataupun pasar tradisional, karena RPH kategori II menghasilkan produk atau karkas dingin dan/atau beku yang sudah dikemas, artinya karkas sudah dibagi menjadi potongan-potongan komersil dan dapat menyesuaikan permintaan pasar. Begitu juga pada edible offal yang ditangani dengan baik, jeroan dibersihkan kemuadian dilakukan pemisahan sesuai dengan bagianbagian yang diinginkan oleh pasar.

Analisis nilai tambah digunakan untuk mengetahui besarnya nilai tambah yang terdapat pada RPH besarnya analisis nilai tambah untuk satu kali proses produksi pada penanganan dan pemotongan Sapi dapat dilihat pada Tabel 2.

Persentase karkas yang dihasilkan oleh RPH PT. Sumber Makanan Sehat sebesar 55\% dan 54\% pada RPH PT. Elders, sedangkan pada RPH kategori I berturut-turut sebesar 54\% dan 50\%. Persentase karkas paling rendah dihasilkan oleh RPH kategori I di RPH Jebrot Cianjur,hal ini disebabkan rataan bobot hidup sapi pada RPH Jebrot lebih kecil dibandingkan RPH lainnya yaitu sebesar 451.4 Kg sedangkan pada RPH kategori II sebesar 533,75. 
Tabel 2. Analisis nilai tambah RPH sapi Kategori I dan II

\begin{tabular}{|c|c|c|c|c|c|}
\hline \multirow[t]{2}{*}{ Peubah / Variabel } & \multirow[t]{2}{*}{ Satuan } & \multicolumn{2}{|c|}{ RPH Kategori I } & \multicolumn{2}{|c|}{ RPH Kategori II } \\
\hline & & A & $\mathrm{B}$ & A & $\mathrm{B}$ \\
\hline \multicolumn{6}{|l|}{ Output,input dan harga } \\
\hline Output Sapi & $\mathrm{Kg} /$ proses produksi & $2.005,95$ & $1.794,00$ & $2.068,76$ & $2.267,00$ \\
\hline Karkas & $\mathrm{Kg}$ & $1.428,00$ & $1.134,00$ & $1.350,49$ & $1.450,00$ \\
\hline Edible Offal & $\mathrm{Kg}$ & 578 & 660 & 718,27 & 817 \\
\hline Input Sapi & $\mathrm{Kg} /$ proses produksi & $2.641,00$ & $2.257,00$ & $2.455,00$ & $2.668,76$ \\
\hline Input tenaga kerja & HOK/proses produksi & 5 & 5 & 4,8 & 4,8 \\
\hline Karkas & HOK & 2,7 & 2,51 & 2,64 & 2,61 \\
\hline Edible Offal & $\mathrm{HOK}$ & 2,8 & 2,49 & 2,16 & 2,19 \\
\hline \multicolumn{6}{|l|}{ Faktor konversi sapi } \\
\hline Karkas & $\mathrm{Kg}$ output/Kg bahan baku & 0,54 & 0,5 & 0,55 & 0,54 \\
\hline Edible Offal & $\mathrm{Kg}$ output/Kg bahan baku & 0,22 & 0,29 & 0,29 & 0,31 \\
\hline Koefisien tenaga kerja & $\mathrm{HOK} / \mathrm{Kg}$ bahan baku & 0,002 & 0,002 & 0,002 & 0,002 \\
\hline Karkas & $\mathrm{HOK}$ & 0,001 & 0,001 & 0,001 & 0,001 \\
\hline Edible Offal & $\mathrm{HOK}$ & 0,001 & 0,001 & 0,001 & 0,001 \\
\hline \multicolumn{6}{|l|}{ Harga Output } \\
\hline Karkas & $\mathrm{Rp} / \mathrm{Kg}$ & 92.000 & 94.000 & 125.000 & 128.000 \\
\hline Edible Offal & $\mathrm{Rp} / \mathrm{Kg}$ & 20.000 & 25.000 & 32.000 & 33.000 \\
\hline Upah rata-rata tenaga kerja & $\mathrm{Rp} /$ proses roduksi & 15.000 & 13.000 & 16.000 & 15.000 \\
\hline \multicolumn{6}{|l|}{ Pendapatan dan keuntungan } \\
\hline Harga input bahan baku & $\mathrm{Rp} / \mathrm{Kg}$ & & & & \\
\hline Karkas & $\mathrm{Rp} / \mathrm{Kg}$ & 23.791 & 22.107 & 24.204 & 23.906 \\
\hline Edible Offal & & 1.250 & 2.900 & 2.610 & 2.930 \\
\hline Sumbangan input lain & $\mathrm{Rp} / \mathrm{kg}$ & 30 & 50 & 200 & 150 \\
\hline \multicolumn{6}{|l|}{ Nilai Output } \\
\hline Karkas & $\mathrm{Rp} / \mathrm{Kg}$ & 49.745 & 47.229 & 68.762 & 69.545 \\
\hline Edible Offal & $\mathrm{Rp} / \mathrm{Kg}$ & 4.377 & 7.311 & 9.362 & 10.102 \\
\hline \multicolumn{6}{|l|}{ Nilai tambah } \\
\hline Karkas & $\mathrm{Rp} / \mathrm{Kg}$ & 25.924 & 25.072 & 44.358 & 45.489 \\
\hline Edible Offal & $\mathrm{Rp} / \mathrm{Kg}$ & 3.097 & 4.361 & 6.552 & 7.022 \\
\hline \multicolumn{6}{|l|}{ Rasio nilai tambah } \\
\hline Karkas & $\%$ & 52,11 & 53,09 & 64,51 & 65,41 \\
\hline Edible Offal & $\%$ & 70,75 & 59,65 & 69,19 & 69,51 \\
\hline Pendapatan tenaga kerja & & 28,4 & 28,8 & 31,28 & 26,98 \\
\hline Karkas & $\mathrm{Rp} / \mathrm{Kg}$ & 15,36 & 14,47 & 17,21 & 14,66 \\
\hline Edible Offal & $\mathrm{Rp} / \mathrm{Kg}$ & 13,04 & 14,33 & 14,07 & 12,32 \\
\hline \multicolumn{6}{|l|}{ Bagian tenaga kerja } \\
\hline Karkas & $\%$ & 0,06 & 0,06 & 0,04 & 0,03 \\
\hline Edible Offal & $\%$ & 0,42 & 0,33 & 0,21 & 0,18 \\
\hline Keuntungan RPH & $\mathrm{Rp} / \mathrm{Kg}$ & & & & \\
\hline Karkas & $\mathrm{Rp} / \mathrm{Kg}$ & 25.908 & 25.057 & 44.341 & 45.475 \\
\hline Edible Offal & $\mathrm{Rp} / \mathrm{Kg}$ & 3.084 & 4.346 & 6.538 & 7.010 \\
\hline \multicolumn{6}{|l|}{ Bagian Keuntungan } \\
\hline Karkas & $\%$ & 52,08 & 53,05 & 64,48 & 65,39 \\
\hline Edible Offal & $\%$ & 70,46 & 59,45 & 69,84 & 69,39 \\
\hline
\end{tabular}

Balas jasa untuk faktor produksi

Marjin 


\begin{tabular}{|c|c|c|c|c|c|}
\hline Karkas & $\mathrm{Rp} / \mathrm{Kg}$ & 25.954 & 25.122 & 44.558 & 45.639 \\
\hline Edible Offal & $\mathrm{Rp} / \mathrm{Kg}$ & 3.127 & 4.411 & 6.752 & 7.172 \\
\hline \multicolumn{6}{|c|}{ Pendapatan tenaga kerja } \\
\hline Karkas & $\%$ & 0,06 & 0,06 & 0,04 & 0,03 \\
\hline Edible Offal & $\%$ & 0,42 & 0,32 & 0,21 & 0,17 \\
\hline \multicolumn{6}{|c|}{ Sumbangan input lain } \\
\hline Karkas & $\%$ & 0,12 & 0,2 & 0,45 & 0,33 \\
\hline Edible Offal & $\%$ & 0,96 & 1,13 & 2,96 & 2,09 \\
\hline \multicolumn{6}{|l|}{ Keuntungan } \\
\hline Karkas & $\%$ & 99,83 & 99,74 & 99,51 & 99,64 \\
\hline Edible Offal & $\%$ & 98,62 & 98,54 & 96,83 & 97,74 \\
\hline
\end{tabular}

Sesuai dengan pernyataan Pradana (2014) bobot badan sapi berpengaruh terhadap bobot karkas yang dihasilkan, semakin besar bobot potong sapi maka semakin meningkat pula bobot karkasnya. Produk utama dari RPH adalah karkas, seekor sapi potong dianggap baik apabila dapat menghasilkan karkas sebesar 55\% dari bobot badan sapi dan diperoleh 46,50\% daging yang dapat dikonsumsi. Karkas Brahman Cross bervariasi antara 45\%-55\% tergantung kondisi sapi saat ditimbang hidup dan performan tiap individunya (Mustofa, 2001).

Soeparno (2005) menyatakan bahwa bobot potong yang tinggi menghasilkan karkas yang makin besar sehingga diharapkan bagian daging menjadi lebih besar. Jenis kelamin mempengaruhi pertumbuhan jaringan dan komposisi karkas.

Input tenaga kerja yang dihitung pada penelitian ini adalah semua tenaga kerja yang berperan dalam proses produksi penanganan dan pemotongan sapi di RPH Kategori I sebesar 5 HOK, RPH Kategori II sebesar 4,8 HOK. RPH kategori I memiliki tenaga kerja lebih banyak dibandingkan RPH kategori II karena pada RPH Kategori I proses penanganan dan pemotongan masih dilakukan secara tradisional. Satu ekor sapi dikerjakan oleh 5 orang tenaga kerja dengan waktu rata-rata 60 menit. Sedangkan pada RPH kategori II dalam 30 menit dapat mengerjakan satu ekor sapi dengan jumlah 4 orang tenaga kerja. Perbedaan input tenaga kerja disebabkan RPH kategori II lebih banyak menggunakan peralatan mekanis dibandingkan dengan RPH Kategori I yang masih menggunakan peralatan manual atau pelibatan tenaga kerja.

\section{Keuntungan}

Keuntungan merupakan selisih antara penerimaan total dengan biaya total. Besarnya keuntungan untuk tiap kali proses produksi pada penanganan dan pemotongan Sapi pada RPH Kategori I dan II dapat dilihat pada Tabel 3.

Tabel 3. Keuntungan RPH Kategori I dan RPH Kategori II

\begin{tabular}{lcccc}
\hline Peubah/ & \multicolumn{2}{c}{ RPH Kategori I } & \multicolumn{2}{c}{ RPH Kategori II } \\
Variabel & $\mathrm{A}$ & $\mathrm{B}$ & $\mathrm{A}$ & $\mathrm{B}$ \\
\hline $\begin{array}{l}\text { Karkas } \\
(\mathrm{Rp})\end{array}$ & 25.908 & 25.057 & 44.341 & 45.475 \\
$\begin{array}{l}\text { Edible } \\
\text { Offal (Rp) }\end{array}$ & 3.084 & 4.346 & 6.538 & 7.010 \\
\hline
\end{tabular}

Pada Tabel 3 dapat diketahui bahwa keuntungan karkas untuk setiap kali proses produksi RPH Kategori I lebih kecil dibandingkan RPH kategori II. Hal ini dikarenakan pada RPH kategori I rantai pasok daging sapi lebih panjang dibandingkan RPH kategori II, pada RPH kategori I produk yang dihasilkan didistribusikan oleh pedagang besar, pedagang kecil, pedagang pengecer, dan kemudian sampai kepada konsumen.

Pada RPH kategori II terjadi proses pelayuan (aging) dan pembagian potongan karkas (wholesale cuts). Potongan karkas (wholesale cuts) sangat berpengaruh besar terhadap keuntungan, karena setiap bagian memiliki harga yang berfariasi dan memiliki pasar yang lebih luas, sedangkan yang terjadi di RPH kategori I proses penanganan sapi setelah dipotong hanya sampai pada karkas panas kemudian dijual dengan harga seragam.

\section{Nilai Output dan Sumbangan Input Lain}

Sumbangan input lain meliputi biaya listrik dan air, biaya perawatan alat, biaya peluru stuning gun dan biaya pengemasan. Total sumbangan input lain adalah pada RPH kategori I adalah Rp 30 dan Rp 50, sedangkan pada RPH kategori II Rp 200 dan Rp 150 per proses. hal tersebut dapat dilihat pada Tabel 4.

Nilai Output adalah hasil kali persentase karkas/ edible offal dengan harga jual produk yang dihasilkan. Total Nilai Output yang dihasilakan terlihat bahwa RPH Kategori II memiliki nilai output yang lebih besar dibandingkan dengan RPH Kategori I. Karena pada RPH kategori II harga output atau harga jual produk jauh lebih tinggi dibandingkan dengan RPH kategori I. menurut Prastowo (2008), bahwa salah satu faktor yang mempengaruhi harga eceran komoditas adalah besarnya marjin keuntungan yang ditetapkan oleh setiap mata rantai distribusi.

\section{Nilai Tambah}

Terdapat beberapa variabel penting yang terkait dengan analisis nilai tambah yaitu faktor konversi yang menunjuk pada banyaknya output yang dihasilkan dari satu satuan input; faktor koefisien tenaga kerja yang menunjuk pada banyaknya tenaga kerja langsung yang diperlukan untuk mengolah satu satuan input; dan nilai produk yang menunjuk pada nilai output yang dihasilkan dari satu satuan input (Hayami 1987).

Nilai output merupakan hasil kali dari faktor konversi dengan harga produk rata-rata. Besarnya nilai 
Tabel 4. Nilai output dan sumbangan input lain

\begin{tabular}{lcccc}
\hline \multirow{2}{*}{ Peubah / Variabel } & \multicolumn{2}{c}{ RPH Kategori I } & \multicolumn{2}{c}{ RPH Kategori II } \\
\cline { 2 - 5 } & $\mathrm{A}$ & $\mathrm{B}$ & $\mathrm{A}$ & $\mathrm{B}$ \\
\hline $\begin{array}{l}\text { Sumbangan input } \\
\text { lain (Rp/kg) }\end{array}$ & 30 & 50 & 200 & 150 \\
Nilai Output & & & & \\
Karkas (Rp/Kg) & 49.745 & 47.229 & 68.762 & 69.545 \\
Edible Offal & 4.377 & 7.311 & 9.362 & 10.102 \\
$(\mathrm{Rp} / \mathrm{Kg})$ & & & & \\
\hline
\end{tabular}

produk/output pada perhitungan nilai tambah untuk karkas dan edible offal pada Rumah Pemotongan Hewan Kategori I dan II berturut-turut adalah Rp 49.745 per kg, Rp 4.377 dan Rp 47.229 per kg, Rp 7.311, sedangkan pada RPH kategori II berturut-turut sebesar Rp 68.762 per kg Rp 9.362 dan Rp 69.545 per kg Rp 10.102, dengan demikian RPH kategori II memiliki nilai Tambah lebih besar dibandingkan dengan RPH kategori I. Hal itu dapat dilihat pada Tabel 5.

Nilai output yang lebih baik pada RPH kategori II dikarenakan harga output atau harga jual produk dari RPH kategori II lebih tinggi dibandingkan RPH kategori I maka hasil dari nilai output tersebut dikurangi biaya dari sumbangan input lain dan biaya dari bahan baku maka diperoleh besarnya nilai tambah berturut-turut sebesar Rp 44.358, Rp 45.489 per kg karkas dan Rp 6.552, Rp 7.022 untuk $1 \mathrm{~kg}$ pada edible offal.

Apabila nilai tambah tersebut dibagi dengan nilai produk maka akan diperoleh rasio nilai tambah sebesar $52,11 \%$ dan $70,75 \%$ pada RPH kategori I untuk karkas dan Edible offal sedangkan pada RPH kategori II sebesar
$64,51 \%$ untuk karkas dan 69,99\% untuk edible offal. Rasio nilai tambah dari RPH kategori II lebih besar daripada RPH kategori I, hal ini dikarenakan RPH kategori II lebih menjaga kualitas produknya dengan mengganti dari padat karya menjadi padat modal.

Bagian tenaga kerja merupakan hasil perkalian antar koefesien tenaga kerja dengan upah rata-rata. Pada perhitungan nilai tambah di atas,imbalan tenaga kerja yang diberikan dari setiap kilogram RPH kategori I pada rumah pemotongan hewan bubulak adalah $0,06 \%$ untuk karkas dan $0.42 \%$ untuk edible offal, sedangkan pada RPH kategori II pada rumah pemotongan hewan PT sumber makanan sehat adalah 0,04\% utnuk karkas dan 0,21\% untuk edible offal, nilai imbalan tenaga kerja ditentukan oleh jumlah tenaga kerja yang terlibat dalam suatu usaha. Analisis lebih lanjut pada RPH kategori I menunjukkan keuntungan yang diperoleh adalah $\mathrm{Rp} 25.908$ dan Rp 25.057 untuk karkas Rp 3.084 dan Rp 4.346 untuk edible offal, dengan tingkat keuntungan sebesar $52,08 \%$ dan $70,46 \%$ serta $53,05 \%$ dan 59,45\%, jumlah ini cukup besar dari skala usaha yang ada bahkan bagian keuntungan per kg bahan baku yang diperoleh tidak lebih besar dibandingkan RPH kategori II. Hal ini dapat dilihat pada RPH kategori II yang memperoleh keuntungan sebesar Rp 44.341 dan Rp 45.475 untuk karkas dengan Bagian keuntungan 64,48\% dan 65,39\% untuk karkas.

\section{Balas Jasa Untuk Faktor Produksi}

Hasil analisis nilai tambah dapat menunjukkan marjin dari RPH kategori I dan RPH kategori II yang didistribusikan kepada imbalan tenaga kerja, sumbangan input lain, dan keuntungan perusahaan. Marjin ini merupakan selisih antara

Tabel 5. Nilai tambah, rasio nilai tambah, pendapatan tenaga kerja

\begin{tabular}{|c|c|c|c|c|}
\hline \multirow[t]{2}{*}{ Peubah / Variabel } & \multicolumn{2}{|c|}{ RPH Kategori I } & \multicolumn{2}{|c|}{ RPH Kategori II } \\
\hline & A & $\mathrm{B}$ & A & $\mathrm{B}$ \\
\hline \multicolumn{5}{|l|}{ Nilai tambah } \\
\hline Karkas $(\mathrm{Rp} / \mathrm{Kg})$ & 25.924 & 25.072 & 44.358 & 45.489 \\
\hline Edible offal $(\mathrm{Rp} / \mathrm{Kg})$ & 3.097 & 4.361 & 6.552 & 7.022 \\
\hline \multicolumn{5}{|l|}{ Rasio nilai tambah } \\
\hline Karkas $(\%)$ & 52,11 & 53,09 & 64,51 & 65,41 \\
\hline Edible offal (\%) & 70,75 & 59,65 & 69,99 & 69,51 \\
\hline Pendapatan tenaga kerja $(\mathrm{Rp} / \mathrm{Kg})$ & 28,4 & 28,8 & 31,28 & 26,98 \\
\hline Karkas $(\mathrm{Rp} / \mathrm{Kg})$ & 15,36 & 14,47 & 17,21 & 14,66 \\
\hline Edible offal $(\mathrm{Rp} / \mathrm{Kg})$ & 13,04 & 14,33 & 14,07 & 12,32 \\
\hline \multicolumn{5}{|l|}{ Bagian tenaga kerja (\%) } \\
\hline Karkas $(\%)$ & 0,06 & 0,06 & 0,04 & 0,03 \\
\hline Edible offal (\%) & 0,42 & 0,33 & 0,21 & 0,18 \\
\hline \multicolumn{5}{|l|}{ Keuntungan RPH } \\
\hline Karkas $(\mathrm{Rp} / \mathrm{Kg})$ & 25.908 & 25.057 & 44.341 & 45.475 \\
\hline Edible offal $(\mathrm{Rp} / \mathrm{Kg})$ & 3.084 & 4.346 & 6.538 & 7.010 \\
\hline \multicolumn{5}{|l|}{ Persentase Keuntungan } \\
\hline Karkas (\%) & 52,08 & 53,05 & 64,48 & 65,39 \\
\hline Edible offal (\%) & 70,46 & 59,45 & 69,84 & 69,39 \\
\hline
\end{tabular}


nilai produk dengan harga sapi per kg bobot hidup. setiap penanganan dan pemotongan $1 \mathrm{~kg}$ sapi diperoleh marjin sebesar Rp 25.954 yang didistribusikan untuk masingmasing faktor yaitu pendapatan tenaga kerja langsung $0,06 \%$, sumbangan input lain $0,12 \%$,dan keuntungan perusahaan $99,83 \%$.

Hasil penelitian Hastang dan Asnawi (2015) menyebutkan semakin panjang saluran pemasaran sapi potong maka marjin dan keuntungan pemasaran semakin besar. Hal ini yang menyebabkan RPH kategori II memiliki marjin yang lebih besar karena pada RPH kategori II hasil produk yang dihasilkan dapat dijual langsung sampai ke konsumen.

\section{KESIMPULAN}

RPH kategori II menghasilkan nilai tambah sebesar Rp 44.358 dan Rp 45.489 per $1 \mathrm{~kg}$ karkas dan Rp 6.552 dan Rp 7.022 per $1 \mathrm{~kg}$ edible offal sedangkan pada RPH kategori I nilai tambah yang dihasilkan jauh lebih rendah yaitu sebesar Rp 25.924 dan Rp 25.072 per $1 \mathrm{~kg}$ karkas dan Rp 3.097 dan Rp 4.361 per $1 \mathrm{~kg}$ edible offal. Perbedaan nilai tambah ini dipengaruhi oleh beberapa faktor salah satu faktor yang sangat berpengaruh adalah harga jual dari nilai produk tersebut, pada RPH Kategori II terdapat proses pelayuan daging (aging), dan pendinginan (cooling) serta pengemasan daging yang terbagi menjadi Prime Cut, Secondary Cut, Bone, dan by Product ini yang menjadikan harga dari setiap bagian memiliki nilai yang lebih. Berbeda dengan RPH kategori I, pada RPH ini sapi hanya diproses sampai karkas hangat yang di belah menjadi 4 bagian tanpa pelayuan dan pengemasan yang kemudian didistribusikan ke pasar-pasar tradisional.

\section{DAFTAR PUSTAKA}

Undang Undang RI No. 41 Tahun 2014. Tentang peternakan dan kesejahteraan hewan. Kementrian Pertanian.

[BPS] Badan Pusat Statistik. 2014. Pendataan sapi potong, sapi perah dan kerbau 2014 (PSPK 2014). Jakarta (ID): Badan Pusat Statistik.

[BSN] Badan Standarisasi Nasional. 1999. SNI tentang Rumah Potong Hewan No. 01-6159-1999. Pusat Standarisasi LIPI Jakarta.

Direktorat Jenderal Peternakan. 2007. Statistik Peternakan. Direktorat Jenderal Peternakan, Jakarta.

Hastang, R Mappangaja, R Darma. I Sudirman, SN Sirajuddin. Analisis keuntungan agribisnis jagal sapi berdasarkan sistem pengadaan dan penjualan. Makasar
Hayami Y, Kawagoe T, Morooka Y, Siregar, Musdjidin. 1987. Agricultural marketing and processing in uplandJava. A perspective from a Sunda village. Bogor: CGPRT Centre.

Kementrian Pertanian. 2010. Peraturan Menteri Pertanian No. 13/Permentan/Ot.140/1/2010 Tentang Persyaratan rumah potong hewan ruminansia dan unit penanganan daging (meat cutting plant). Berita Negara RI No. 60/2010.

Mustofa, Z. 2001. Analisis pemasaran sapi potong di kabupaten blora Jawa tengah. Prosiding Seminar. Fakultas Peternakan Institut Pertanian Bogor. Bogor

Saragih B. 2010. Suara Agribisnis : Kumpulan Pemikiran Bungaran Saragih. Jakarta (ID): PT Permata Wacana Lestari.

Soeparno. 2005. Ilmu dan teknolongi daging. Gajah Mada University Press. Daerah Istimewa Yogyakarta

Tawaf R. 2012. Standarisasi manajemen rumah potong hewan milik pemerintah di Jawa Barat. 